\title{
Housing Affordability in Ghana: A focus on Kumasi and Tamale *Nicholas Addai Boamah
}

\begin{abstract}
There are insufficient affordable housing units in Ghana. Most of the available units are poorly developed and are not habitable. The paper explores the affordable housing situation in Ghana by using Kumasi and Tamale as study area. It determines whether housing - housing credit, and rental and owner occupied units are affordable. It also determines the extent to which government interventions have been successful in providing affordable housing for Ghanaians. It examines the contribution of the formal finance institutions to the provision of affordable housing in Ghana. It does so by surveying the literature on affordable housing. It also evaluates the affordable housing delivery system in Ghana. It found that housing units with basic acceptable standards are unaffordable by many households in the study areas. Also, most households in Kumasi and Tamale cannot afford mortgage credit, and adequate rented and owner occupied housing units due to low income levels, high unemployment rate, and high interest rates. It notes that interventions by government have been unsuccessful in providing affordable housing in the country.
\end{abstract}

Keywords-Affordable Housing, Government Interventions, Formal Finance, Households, Ghana

\section{Introduction}

ffordable housing encompasses
not only the static structure called a house but the entire spectrum of environmental factors that make living acceptable and comfortable. Among them are good access routes, ventilation, sanitation and access to basic human need such as water. Housing affordability therefore involves the ability of households to consume other basic necessities of life such as food and clothing in addition to accessing adequate housing. It includes the ability of households to consume housing that permits reasonable standard of living, ability of mortgagors to effectively meet mortgage obligations, and households' access to adequate standard of housing without denying them access to other basic necessities of life. Housing affordability therefore encompasses not only the cost of housing but also housing standards, environmental factors, the price of other necessities of life and the cost of mortgages. Though a basic good, the provision of affordable housing exerts great stress on every nation's means to deliver. Housing, particularly affordable housing for the low-income people is highly complex and capital intensive for all parties involved (CHF, 2004). It should be noted, however, that the minimum acceptable housing standards differ from country to country, depending on geographical and economic conditions. In general, acceptable standards rise with income levels, and what is included in the home also expands.

The benefit of quality affordable housing to every nation is extremely massive; it impacts on the economic, socio-cultural and political life of people; it provides shelter for sleep; serve as a shield against elements of the weather and other hazards; it affects efficiency and stability of a whole economy and financial markets; and hence has a significant impact on the productivity and growth of all nations. Affordable housing is a foremost economic, political and social issue in a developing country like Ghana. It is therefore not surprising that quality affordable housing is cardinal to all households and the economic development pursuit of nations. However, for the benefit of this basic good to be attained by any country, it needs to be affordable by many households. But, this is not the case in Ghana.

There is insufficient housing in Ghana and even most of the available houses are poorly developed and lack the basic amenities required to make them habitable (Boamah, 2010). Ghana suffers from a severe housing deficit as a result of low housing delivery relative to households' growth. The Home Finance Company Limited (HFC-now HFC Bank Ltd) estimated in 2002, that the country had an estimated unsatisfied housing need of $1,232,835$ units, with an estimated new annual demand of 133,000 units. However, only 25,000 units are produced annually leaving an unsatisfied annual demand of 108,000 units. More than $52 \%$ of houses in Ghana accommodate between two (2) and four (4) households (Ghana Statistical Service (GSS), 2002). Mahama and Antwi (2006) suggested that the housing deficit in Ghana stood at 1,526,275 housing units. In 2000 the housing deficit in Kumasi was 164,219 (GSS, 2005a) and Tamale was 18,690 (GSS, 2005b) housing units. As a result of the insufficiency of housing in the country a great number of 
Ghanaians now "sleep rough", particularly in the major cities like Accra, Kumasi, Tema, Sekondi-Takoradi and Tamale. For instance, $1.9 \%$ of the Ghanaian population rely on shift dwelling units such as kiosks, tents, cargo containers, attachment to shops, and offices for shelter; this is in addition to the $3 \%$ who are homeless (GSS, 2002) and live on the streets, lorry parks, and markets. About 6,000 households in Kumasi and about 1,700 households in Tamale sleep either on the streets, markets, lorry parks, or in front of shops (GSS, 2005a,b).

Most households are unable to consume housing with adequate standards, good environmental factors, and also meet other basic necessities of life. The paper explores the affordable housing situation in Ghana and determines whether housing is affordable to Ghanaians. It also examines the contribution of individual households and the formal finance institutions to the provision of affordable housing in Ghana. The study determines the impact of government interventions on the provision of affordable housing to Ghanaians.

\section{Study Area}

The paper used Kumasi and Tamale as study areas. Kumasi and Tamale were chosen because they are both major cities; Kumasi (located in southern Ghana) is the second largest city of Ghana whilst Tamale is the major city in the Northern part of Ghana. The choice of Kumasi and Tamale therefore enables a comparison of the affordable housing situation in the Northern and Southern parts of the country. Kumasi is the capital of the Ashanti Region of Ghana and the seat of the ancient Asante kingdom. The indigenous people in Kumasi are the Asantes but the city is highly multiethnic. Tamale on the other hand is the capital of the Northern Region of Ghana. It is also multiethnic with the indigenous people been the Dagombas.

\section{Methodology}

The paper surveyed the literature on affordable housing. It also evaluated the housing market to determine the extent to which housing is affordable to Ghanaians. Field survey was carried out in both Kumasi and Tamale from late July to the end of September, 2010 to collect empirical data. Data were collected from households in both cities. The study selected three (3) neighbourhoods each from the North-East, North-West, South-East, and South-West quadrants of both cities (see Table 1). This approach ensured that the selected neighbourhoods fully reflected the study area. Fifteen housing units were selected from each of the selected neighbourhoods using systematic sampling technique at intervals of every tenth house. One-Twenty (120) housing units each from Kumasi and Tamale were sampled for the study. Data were obtained from all households in the selected housing units. A total of 423 and 252 households from Kumasi and Tamale respectively took part in the study. Questionnaires were used to collect data from the respondents. It used personal interviews to obtain data on house prices in both Kumasi and Tamale from the officials of Goldstreet Real Estate Consult (GREC). The paper also obtained secondary data from the existing literature and official sources such as the HFC, Ghana Statistical Service (GSS) and from official documents such as the housing policies of Ghana. Secondary data was gathered through archival and official documentary surveys.

\section{Individual Households and Housing Delivery in Ghana}

Most households in Ghana use their long-term savings, sweat equity, and loans and remittances from family members to build their houses through the incremental building process. Individual households deliver about 90\% of the housing stock in Ghana (MWH, 1999). CHF (2004) suggests that informal ways of incrementally developing and building housing creates a greater supply of affordable housing in Ghana. Housing supply in Ghana is driven by households rather than real estate developers or government (Bank of Ghana (BoG), 2007). The usual means adopted by households is to purchase a bare land and then start a protracted process of incrementally building their housing units. The annual housing delivery of about 30,000 units is mostly done through informal processes; the formal real estate developers produce only 2,500 units at its peak (Akuffo, 2006). The informal sector thus delivers about $92 \%$ of the annual housing output in the country. But as Smet (1996) notes it is both expensive and ineffective to provide housing through the incremental building process. This means of delivering housing greatly increases the construction cost of dwellings and also locks up funds that could be invested in incomegenerating ventures in properties for excessively long periods without any returns (Boamah, 2009). 
The incremental building process is highly expensive, waste resources, and sometimes the properties become aesthetically and functionally obsolete on completion.

\section{Policy Interventions and Housing Delivery in Ghana}

The Ghana government's involvement in affordable housing provision has been done through various housing policy initiatives and programmes. The emphasis of the various policies, however, differed and depended mostly on the political ideology of the implementing government. During the colonial era housing policies did not cater for the housing need of the population at large. Housing delivery by the colonial government were limited to the provision of army and police barracks, single rooms for civil servants and miners, and bungalows for senior civil servants (Owusu and Boapeah, 2003). The colonial government made available serviced building plots but these were leased only to the affluent members of the population. There was no emphasis on affordable housing delivery during the colonial era. The only major housing projects during this era were the development of the New Zongo Estates in 1929 and the establishment of Labadi and James Town in 1939 to provide housing for the victims of the 1924 plague in Kumasi and the 1939 earthquake in Accra respectively. The free market system, regulated households access to land for low income housing during the colonial era (Songsore, 2003).

Post independence housing policies focused primarily on direct housing construction, provision of subsidized housing loans, the provision of subsidized construction finance and housing market liberalization. The government intervened through public housing provision and either demand or supply side subsidy. Public sector housing in Ghana was delivered through the State Housing Corporation (SHC -now the State Housing Company Limited) and the Tema Development Corporation (TDC). For instance between 1957 and 1966 the TDC and SHC respectively delivered 10,700 and 1,052 low-cost housing units. Also from 1972 to 1979 the TDC delivered 7,380 subsidized housing units. Konadu-Agyemang (2001) notes that the SHC produced 23,000 housing units between 1955 and 1981. Examples of the public housing units are the North Suntreso, South Suntreso and Patasi estates in Kumasi; Kalpahini and Vitting Estates in Tamale; Twumasen quarters at Offinso; and the TDC estates in Tema. All the public housing units have been sold either to the sitting tenants or to the general public and the institutions fully or partiallyliberalized; there is no public housing in Ghana at the moment. The SHC for instance currently builds a limited number of middle-income housing units for sale to the public.

Housing subsidies was another avenue through which the government provided affordable housing. For instance, between 1957 and 1966 the government granted $£ \mathrm{G} 2,150,000$ as concessionary housing loans, provided roof loans of $£ \mathrm{G} 200$ each to over 3,000 Ghanaians at a concessionary interest rate of $2.5 \%$ p.a, and offered rental subsidies to the occupants of the laborers quarters (Government of Ghana, 1959). Also, the government established the defunct Bank for Housing and Construction (BHC) to provide concessionary construction finance to housing developers and concessionary loans to homebuyers. The BHC granted a total $ф 223,895,588$ housing loans to 363 mortgagors by 1988 (Konadu-Agyemang, 2001). The liberalization of the housing sector in 1987 led to the inauguration of the Ghana Real Estate Developers Association (GREDA) in 1988 and the establishment of the HFC in 1991. The onus of housing delivery was therefore vested in the private sector. The HFC for instance granted a total of US\$44.4 (in millions) to 3,639 mortgagors by 2001. GREDA members have for the past 8 years constructed about 10,954 housing units (BoG, 2007).

\section{Formal Finance and Housing Delivery in Ghana}

The formal finance institutions have made minimal contribution to housing delivery in Ghana. For instance, the total mortgages originated by the HFC in 2001 were US $\$ 4.9$ million; about $95 \%$ of all mortgages created in Ghana for 2001 (HFC, 2001). The financial institutions have demonstrated that they attach little importance to mortgages as a form of investment (Boamah, 2010). The Commercial Banks have not been interested in housing finance; they focus on Treasury Bills and Bonds (Akuffo, 2006). High inflation rates have increased the credit, interest rate and liquidity risks for lenders in Ghana (Boamah, 2009). Long and medium term investments (such as housing credits) were therefore disfavoured by most banks. Though there is potentially large market size, the mortgage products in the country are inadequate; only 
few banks provide funds for housing investment, especially to their few worthier customers. The banks investments in the housing sector are insignificant. The financial institutions have provided extremely limited affordable housing finance to households in Ghana. The outstanding mortgages in the country are about US\$50 million and the share of housing credit in the total loans of the banks are marginal (Bo G, 2007). None of the commercial banks have specific, stand alone departments that engage in home mortgage finance (CHF, 2004). The ratio of Mortgage Debt Outstanding (MDO) to Gross Domestic Product (GDP) was $2.5 \%$ in 2004 and $3.9 \%$ in 2006 (BoG, 2007) indicating that the mortgage market is under-developed.

\section{Housing Stock and Need in Kumasi and Tamale}

There is a continuously rising housing deficit in both Kumasi and Tamale. Increases in the housing stock over the years have not been sufficient to make up for the housing deficit in these cities. For instance, the housing need and stock in 1984 and in 2000 respectively stood at 108,256 and 17,933 , and 231,653 and 67,434 housing units in Kumasi (GSS, 1984a, 2005a). The data suggest that the housing deficit in Kumasi was 90,323 in 1984 and 164,219 in 2000. This implies that between 1984 and 2000 the housing stock in Kumasi increased by $276 \%$, the housing need increased by $114 \%$, and the housing deficit rose by $81.8 \%$. The $2.4 \%$ of households in Kumasi who lived in kiosks and containers in 2000 (GSS, 2005a) gives ample evidence to the housing scarcity in the city. Similarly, the housing need and stock in 1984 and in 2000 correspondingly stood at 23,499 and 9,728, and 45,390 and 26,700 housing units in Tamale (GSS, 1984b, 2005b). The data indicate that the housing deficit in Tamale was 13,771 in 1984 and 18,690 in 2000. In Tamale, between 1984 and 2000 the housing stock and need respectively surged by $174.5 \%$ and $93.2 \%$, and the housing deficit rose by $45.2 \%$. Though the growth in housing stock exceeded the growth in housing need in both Kumasi and Tamale between 1984 and 2000, the increases in the housing stock were not enough to offset the housing deficit in both cities. The housing deficit situation in both Kumasi and Tamale rather worsened between 1984 and 2000. The housing deficit situation is worse in Kumasi than in Tamale. For instance, in 2000, 70.9\% and $41.2 \%$ of households in Kumasi and Tamale respectively were without housing.

\section{Housing Density in Kumasi and Tamale}

The room occupancy ratio of a household is a measure of housing adequacy. Any room occupancy ratio in excess of two persons per room is an indication of overcrowding (GSS, 2005). Households in Kumasi live in higher densities. Table 2 showed the pattern of housing densities in the study area. In Kumasi, the average household size is 5.8 persons; there are 3.5 households (20.3 persons) per house; 2.1 rooms per household; and 2.8 persons per room. The room density data suggest that these households live in overcrowded conditions. Similarly, the average household size in Tamale was 7.4 persons, and the population and number of households per house were respectively 15.5 persons and 2.1 . There are 3.2 rooms per household indicating a room density ratio of 2.3 persons in Tamale; the households live in overcrowded conditions.

The rooms occupied by households serve as their sleeping, living, and dining rooms in both Kumasi and Tamale. Overcrowding and congestion is a characteristic of housing in both cities. The higher average household per house in these cities is a sign of overcrowding. The average households per house in Kumasi exceed that of Tamale by 1.4 households $(66.6 \%)$. Therefore, on the basis of average number of households per house, overcrowding is more severe in Kumasi than in Tamale. The large household size in both cities has exerted pressure on the available housing stock leading to high population per room. The high room occupancy rate has serious health implications; it may facilitate the transfer of communicable diseases among the household members.

\section{Housing Condition in Kumasi and Tamale}

A characteristic of housing in both Kumasi and Tamale is the poor condition of housing. The housing stock is characterised by deteriorating buildings, poorly designed structures, and inadequately maintained housing units. Housing decay is a major problem confronting households in both Kumasi and Tamale. Instances of such deterioration could be found at Aboabo, Moshie Zongo, Akwatialine, Tafo, Sawaba, Anloga, and Ayigya in Kumasi and Vitting, Changli, Dabbifong, Nyohini, and Dagban in Tamale.

A significant proportion of households in both Kumasi and Tamale lack safe bathing facilities. As Table 3 indicates, $19.9 \%$ and $35.7 \%$ of households in Kumasi and Tamale 
correspondingly have no bathing facilities in their housing units. These households rely on open cubicles, open space, and bathhouse in another house for their bathing needs. The difference between households' access to bathing facilities in Kumasi and Tamale is significant. The use of open spaces for bathing purposes in both Kumasi and Tamale provides no security and privacy to the households; it exposes household members, particularly women and children to all forms of attack including rape and verbal assault. Most households in both Kumasi and Tamale lack toilet facilities in their housing units. As shown in Table 3, households in Kumasi depend on public toilet $(35.5 \%)$, in house toilet facility $(64.5 \%)$ and no toilet facility (3.5\%). Similarly, $42.9 \%, 31.7 \%$, and $25.4 \%$ of households in Tamale respectively have no toilet facility, rely on public toilet, and have access to in-house toilet facility.

Households without toilet facilities rely on the bush, farms, rivers or streams, and small receptacles (including plastic bags and "chamber pots") as their toilets. Indiscriminate disposal of human waste is more prevalent in Tamale than in Kumasi. The means of disposing off waste is a matter of great concern as its improper disposal has serious repercussions on environmental health. Housing cannot be adequate if the housing unit exposes its occupants to health and environmental hazards; and/or lacks basic infrastructure such as toilet and waste disposal facilities. Pan latrines and KVIPs are unhygienic; pan latrines are an eyesore and the stench from a KVIP is a significant air pollutant. These do not provide for comfortable living within the house.

Some houses are constructed with poor quality materials such as mud and untreated timber as outer walling, roofing, or flooring material. Table 4 notes that the main material for constructing the outer wall of houses in Tamale are mud/mud brick/earth (42.5\%), cement blocks/concrete (44.2\%), and landcrete (13.3\%). Also, $19.2 \%, 74.2 \%, 3.3 \%$, and $2.5 \%$ of houses are respectively roofed with grass/palm leaf, corrugated metal, asbestos, and concrete. Similarly, the flooring material for $17.5 \%, 78.1 \%$ and $4.4 \%$ of houses in Tamale correspondingly are mud/earth, cement/concrete and other materials (such as terrazzo, tiles and wood) (see Table 4). In Kumasi, the outer wall of $9.2 \%, 87.5 \%$, and $3.3 \%$ of houses are constructed of $\mathrm{mud} / \mathrm{mud}$ brick/earth, cement blocks/concrete, and landcrete in that order (Table 4). The major roofing material for houses in Kumasi are thatch from grass/palm leaf $(2.5 \%)$, corrugated metal (80.8\%), asbestos (4.2\%), concrete $(7.5 \%)$ and wood/earth (5\%); and $4.7 \%, 85 \%$ and $10.8 \%$ of houses in Kumasi respectively have mud/earth, cement/concrete, and other (terrazzo, tiles, wood) as flooring material. Comparatively, houses in Kumasi are constructed with quality materials than houses in Tamale.

The use of certain materials for the construction of houses in both Tamale and Kumasi exposes the occupants to various degrees of environmental and health hazards. For instance, thatch from grass/palm leaf is at best a fire hazard and cannot stand the vagaries of the weather such as rain storm; it offers no protection to the occupying households from the hazardous elements of the world. Asbestos roofing sheets carry serious health hazards; it is not an acceptable roofing material. Mud as a flooring material is unhealthy, leads to dust pollution, and termite and worm invasion. The health and environmental risk resulting from the use of poor quality building materials is more severe in Tamale than Kumasi.

\section{Access to Affordable Housing in Kumasi and Tamale}

Property ownership is a significant aspect of the Ghanaian tradition and culture; houses are owned not only for the sake of shelter but also importantly as a means of social standing and prestige. Quayson (2007) observes that home ownership is very important in the Ghanaian society as it serves a dual purpose of providing shelter and also indicates one's social status and prestige. For many Ghanaians, homeownership is the key to financial security; it is necessary for the attainment of civic pride and family ties; and it also consolidates the extended family system which is an integral part of the Ghanaian tradition and culture. A household may therefore be prepared to save a substantial part of its earnings if that could secure it a house in the near future. Most Ghanaians will sell their houses only under extreme situations (CHF, 2004). Despite the high premium put on homeownership in Ghana, a greater proportion of households in Kumasi and Tamale are either incapable of acquiring a house via their own resources or owning a house in their life time. Households access to housing (both owner occupied and rented) is limited in Kumasi and Tamale. $49.2 \%$ and $71 \%$ of respondents owned their dwelling units in Kumasi and Tamale 
respectively (Table 5). The low level of homeownership, particularly the situation in Kumasi is disturbing for a country where homeownership is an embodiment of its culture. The low level of homeownership in Kumasi relative to Tamale is not surprising given the large number of migrant workers in Kumasi and the high construction cost in Kumasi compared to Tamale. Most households in Tamale are able to construct their own inexpensive dwelling units but mostly with poor building materials (see housing condition). Similarly, the low homeownership rate in both Kumasi and Tamale is expected given the high construction cost in both cities. Renting of houses and rooms is more common in Kumasi than in Tamale. $33.1 \%$ and $24.6 \%$ of respondents in Kumasi and Tamale respectively rented their housing units (Table 5). Family connections play a significant role in securing accommodation. As Table 5 indicates, $17.7 \%$ of respondents in Kumasi and $4.4 \%$ of Tamale respondents live rent free. The kinship and the extended family system play a major role in providing shelter for most households more importantly in Kumasi.

Most households in Kumasi and Tamale are unable to afford rental apartments; they mostly rent single rooms usually in compound houses. The single room occupancy rate is high in Kumasi as compared to tamale. Table 6 indicates that $59.3 \%$ and $33.9 \%$ of respondents who are renting their housing units in Kumasi and Tamale respectively live in one room. Also, only $7.9 \%$ and $4.8 \%$ respectively of respondents in Kumasi and Tamale are able to rent apartments.

There is a wide disparity in housing consumption both in quality and in quantity between the urban rich and poor in both Kumasi and Tamale, and in quality between Kumasi and Tamale. As one travels from Kumasi to Tamale or from the high class communities to the urban slumps in both Kumasi and Tamale; the housing quality, consumption and the adequacy divide is profusely eminent. As have been noted earlier, a significant proportion of households in Tamale use low quality building materials for the construction of their houses relative to those in Kumasi, hence the significant variation in housing quality between the two cities. At one end of the housing market in both Kumasi and Tamale, there are households consuming plush homes with spacious and well-kept compounds, soul inspiring gardens, modern facilities, comfort, and convenience.
Examples are the Nhyiaeso and ridge residential areas in Kumasi and the Jisonayili and Norrip village in Tamale. At the other end there exist households living in dilapidated houses. Examples could be found at AyigyaZongo and Anloga in Kumasi, and Nyohini and Changli in Tamale. Quality housing is generally inaccessible by the urban poor, the rural folks and most people in the northern sector of Ghana.

Mortgage credit is not available to many a Ghanaian household; households in Kumasi and Tamale are not excluded from the credit unavailability problem. The housing sector has been constrained of funding. Neither the builder nor the consumer can readily obtain affordable housing finance in the country; many housing developers have difficulty obtaining funding for their projects (Quayson, 2007). GSS (2008) for instance indicated that only $7.9 \%$ male-headed and $2.1 \%$ femaleheaded households in the country had access to housing credit. Clearly the availability of housing credit to households in Ghana particularly for the female headed households is significantly low.

\section{Why the Current State of Housing in Kumasi and Tamale?}

Several factors are responsible for the poor state of and inadequacy of housing in Kumasi and Tamale. First, the failure of government policy interventions is partly responsible for the poor state of housing in the country as a whole. The formulation of policies and programmes has been quite easy as compared to their implementations; housing policies have generally been unsuccessful. As a result, increases in housing stock have lagged behind population growth countrywide. The failure of the various housing policies may be attributed to frequent policy abandonment due to political instability, lack of coordination, poor management and corruption. The frequent overhauls of housing policies created uncertainty and disorientation which disrupted long-term and sustained programmes of the national housing agencies (Mahama and Antwi, 2006). The national housing agencies were therefore unable to meet their targets under the various housing policies. Tipple (1987) notes that the State Housing Corporation (SHC) was only able to deliver $38 \%$ and $13 \%$ of its targeted output under the 1959-64 and 1967-69 housing policies respectively. Most tenants in SHC rental units also became habitual rent defaulters. Afrane (1986) notes that accumulated rent arrears 
eventually became irrecoverable and were declared bad debts. Corruption in the allocation of public housing units also militated against the success of policy interventions. Public housing intended for particular groups did not reach them (KonaduAgyemang, 2001). Government interventions failed to reach the low income target groups or meet housing requirements (CHF, 2004). Most of the houses earmarked for the low and middle income groups' unfortunately were allocated to the high income groups with the targeted beneficiaries ending up as tenants. Government policy interventions only proved to be highly inefficient, ineffective, and expensive venture in the country.

Second, high unemployment rate, low income levels, and high house prices and rental levels have contributed to the housing inadequacy and poor housing condition in Kumasi and Tamale. The proportion of the economically active population that were unemployed in 2000 stood at $9.2 \%$ and $11.4 \%$ respectively in Tamale and Kumasi (GSS, 2005a, b). The GSS (2008) notes that the mean annual household income was respectively $\mathrm{GH} \phi 1,149$ and $\mathrm{GH} \phi 1,452$, in Ashanti Region (Kumasi) and Northern Region (Tamale) and the mean annual per capita income in Ashanti Region was GH $\notin 410$ and in Northern Region was $\mathrm{GH} \notin 296$. On average, a low-cost house cost GH 445,000 (US\$32,143) in the informal housing market and a three-bedroom house sells for $\mathrm{GH} \phi 70,000(\$ 50,000)$ in the formal housing market. Semi-detached house cost between US\$30,000 and US\$90,000 and detached self-contained house cost between US\$50,000 and US\$110,000 in the formal housing markets (BoG, 2007). Karley (2008) notes that a two bedroom detached house delivered by the parastatals cost between GH $\varnothing 48,000$ and GH $\varnothing 50,000$; a two bedroom semi-detached house delivered by the private real estate developers cost up to $\mathrm{GH} \phi 48,000$; and a low-income housing cost up to GH $\phi 50,000$ (US\$1 = GH $\not 1.40$ ). The monthly rent for a three bedroom flat in a good location cost $\mathrm{GH} \notin 200$ in Kumasi and $\mathrm{GH} \not 160$ in Tamale.

The state of income and unemployment levels and the cost of housing in Kumasi and Tamale clearly indicate that most households in these cities cannot afford rental apartments and owner occupier units. Housing cost is beyond the affordable limit of majority of households in Tamale and Kumasi; housing affordability levels are generally low.
The income and house price data suggest that a household in Kumasi and Tamale would have to save its entire annual income (average annual household income) for at least 39 years and at least 31 years respectively before been able to acquire its own housing unit. Similarly, the annual rental level for a three bedroom apartment is about $208 \%$ and $132 \%$ of average annual household income in Kumasi and Tamale respectively. House prices and rental levels are out of range for most households (Quayson, 2007). Unemployed households and those not in the labour force earn no income and can therefore not acquire their own housing units even if it is subsidized for them. The levels of income and unemployment partly accounts for the inadequacy and poor condition of housing in Kumasi and Tamale.

The housing affordability problem has been intensified by the huge advance payment (1-3 years) that landlords demand from tenants in order for letting to take place. The advance payment for a three bedroom apartment (with basic facilities such as toilets, kitchen, fence wall, bathroom and fan) ranged between GHc2400 (US\$1,714) and GHc7,200 (US\$5,142) in Kumasi and GHc1,920 (US\$1,371.1) and GHc5,760 (US\$4,113.6) in Tamale (see table 7). For single room occupied tenants the advance payment is at least GHc280 (US\$200) in Kumasi. The data indicate that households would have to save all their annual incomes (without any allowance for food, clothing and shelter) for at least 2 years and not less than one year and three months before been able to meet one year advance payment for a three bedroom apartment in Kumasi and Tamale respectively. This constraint of having to make lumpy one year payment in advance has produced a "barrier" to entry into the housing market. The result is that while there is a high demand for quality housing in Kumasi and Tamale, the typical rental agreement has rendered the demand ineffective. Rental apartment has therefore been rendered unaffordable for many a household in these cities.

The income and employment situation has serious implications for the development of shelter and housing loan products (CHF, 2004) since the level, source, and sustainability of a household income impact on the determination of mortgage terms, size, costs, collateral requirements, and repayment methods. The loan obligation must not deny the households of other basic necessities of life but this is not the case for most households in Kumasi and 
Tamale (see table 7). The affordability of mortgage loans is dictated by three main factors namely, house price, income and the mortgage products available. But income levels are extremely low, house prices are overly high, and mortgage designs do not meet the income and payment characteristics of households. Therefore, mortgages are unaffordable by households in Kumasi and Tamale. Most households are incapable of meeting the debt service requirements of residential mortgages. As table 7 indicates, the average payment to income ratio of Kumasi households is $773 \%$ and Tamale is $612 \%$ as opposed to the maximum payment to income ratio of $25 \%$ accepted by lenders. To acquire a low-cost housing a borrower is required to have a minimum annual household income of $\mathrm{GH} \notin 35,536$ (US\$25,379) in order to afford the required annual repayment of $\mathrm{GH} \phi 8,884$ (US\$6,345); this exceeds the incomes of most households. From the mortgagees' perspective, these households cannot afford housing; they cannot satisfy the capacity requirement of lenders. In addition, the high interest rate in Ghana as a result of weak macro-economic environment has worsened the mortgage affordability problem via its effects on mortgage repayments. Table 7 shows that an annual repayment of $\mathrm{GH} \phi 8,884$ (US\$6,345) is required in order for the borrower to fully pay off a mortgage debt of $\mathrm{GH} \phi 31,500$ granted over 20 years. This high annual mortgage repayment has principally been caused by the high rate of interest in Ghana. Mortgages in general are not affordable by a significant proportion of households; they do not meet the basic underwriting criteria and are therefore not qualified.

The down payment requirement has also denied some households access to the housing finance market. The borrower's equity is usually up to $30 \%$ of the property value; this amounts to $\mathrm{GH} \notin 13,500$ (US\$9,641) for a lowincome housing (see table 7). This deposit is a multiple of income which a lot of workers are unable to provide based on their existing incomes. The deposit is $1,175 \%$ and $930 \%$ of the average annual household income of Kumasi and Tamale households respectively. Households in Kumasi would have to save their entire annual incomes for 12 years whilst households in Tamale would be required to save their total annual income for at least 9 years to be able to meet the deposit requirements of lenders. The capital required is a sufficient deterrent to a number of potential borrowers. These security requirements of lenders have disqualified most potential mortgagors from accessing mortgages in Ghana.

\section{Conclusion}

There is housing inadequacy in Kumasi and Tamale. Rental and owner occupied units, and housing credits are unaffordable by most households. Generally, income levels are low and unemployment rates are high thereby disqualifying most households from accessing housing credit of any form. The performance of the formal finance sector in housing financing has not been impressive. The formal finance sector has proved largely unwilling or unable to deliver the form and quantity of financing required for long term housing investment. Various governments of Ghana have implemented different housing policies with the aim of ensuring housing affordability in the country. Most of the housing programs, could not achieve their desired result as a result of mismanagement, lack of coordination, corruption, and the abandonment of the housing policies. Housing is not affordable by many households; they cannot afford adequate housing and still consume other basic necessities of life, they are unable to meet the basic payment to income ratio required by lenders, they generally have low incomes and live in low quality rented rooms. There is therefore, the need to create the necessary framework for the provision of affordable housing both rented and owner occupied in the country. It is equally germane for lenders to offer mortgage products that take into account the income patterns of the low and middle income households. 


\section{References}

Afrane, S.K. (1986). "Review of Analytical Methods in Housing." Ghanaplan Vol. 1 pp. 37-47

Akuffo, A. (2006). HFC'S Pioneering Role and Rational for Conversion to Full Banking Activities: Sustainability of Specialised Lenders. The World Bank/International Finance Corporation (IFC), Housing Finance Conference, 16-17 March, Washing DC, USA. Asare, E. L. and Whitehead, C. (2006), "Formal mortgage markets in Ghana: nature and implications", RICS Research paper series, Vol. 6, No 13, October 2006

Bank of Ghana (2007). The Housing Industry in Ghana: Prospects and Challenges, Bank of Ghana Policy Briefing Paper. Accra: BoG

Boamah, N.A. (2009). "Secondary Mortgage Market (SMM): Is it Right for Financing Housing in Ghana?" Journal of Science and Technology, Vol. 29, pp 17-27.

Boamah, N.A. (2010). "Housing Finance in Ghana: Would Community Mortgage Cooperatives Provide a Panacea?" Ghana Journal of Development Studies, Vol .7, No. 1. CHF International (2004). Strategic Assessment of the Affordable Housing Sector in Ghana, December, 2004.

Ghana Statistical Service (1984a). 1984 Population Census of Ghana, Demographic and Economic Characteristics, Ashanti Region. Accra: GSS

Ghana Statistical Service (1984b). 1984 Population Census of Ghana, Demographic and Economic Characteristics, Northern Region. Accra: GSS

Ghana Statistical Service (2002). 2000 Population and Housing Census of Ghana. Accra: GSS

Ghana Statistical Service (2005a). 2000 Population and Housing Census, Ashanti Regional Analysis. Accra: GSS
Ghana Statistical Service (2005b). 2000 Population and Housing Census, Northern Regional Analysis. Accra: GSS

Ghana Statistical Service (2008). Ghana Living Standards Survey, Report of the Fifth Round (GLSS 5). Accra: GSS

Government of Ghana (1959). The Five Year Development Plan, 1959-1964. Accra: GoG

Karley, N.K. (2008), "Ghana Residential Property Delivery Constraints and Affordability Analysis", Housing Finance International.

Konadu-Agyeman, K. (2001). The Political Economy of Housing and Urban Development in Africa: Ghana's Experience from Colonial Times to 1998. Praeger Publishers, Westport.

Mahama, C. and Antwi, A. (2006). "Land and Property Markets in Ghana", Discussion Paper, Prepared by Royal Institution of Chattered Surveyors, World Urban Forum III, June 1923, 2006.

Owusu, S.E. and Boapeah, S.N. (2003). "Housing Policy in Ghana: Experiences and Interventions for Public/Private Sector Support Systems". Bi-Annual Journal of the Building and Road Research Institute (CSIR), Ghana, Vol. 8.

Quayson, A. (2007). "Ghana Primary Mortgage Market Initiative," Housing Finance International, December, 2008.

Sonsore, J. (2003). "The Urban Housing Crisis in Ghana: Capital, the State versus the People", Ghana Journal of Social Science, vol. 2, pp 131.

Tipple, A. G. (1987). The Development of Housing Policy in Kumasi, Ghana 1901-1981. Newcastle upon Tyne: Center for Architectural Research and Development Overseas. 
Table 1: Study Neighbourhoods

\begin{tabular}{|l|l|l|l|}
\hline Kumasi & Tamale \\
\hline Neighbourhood & Selection Criterion & Neighbourhood & Selection Criterion \\
\hline Adoato & North-West Quadrant & Chogu & North-West Quadrant \\
\hline Bremang & North-West Quadrant & Aboabo & North-West Quadrant \\
\hline Anomangye & North-West Quadrant & Gumani & North-West Quadrant \\
\hline Sepetimpom & North-East Quadrant & Tishigu & North-East Quadrant \\
\hline Buokrom & North-East Quadrant & Sakasaka & North-East Quadrant \\
\hline Old Tafo & North-East Quadrant & Jisonayili & North-East Quadrant \\
\hline Patasi & South-West Quadrant & Lamashegu & South-West Quadrant \\
\hline Edwenase & South-West Quadrant & Dungu & South-West Quadrant \\
\hline Kwadaso & South-West Quadrant & Kakpayili & South-West Quadrant \\
\hline Aboabo & South-East Quadrant & Kukuo & South-East Quadrant \\
\hline Gyenyase & South-East Quadrant & Vitting & South-East Quadrant \\
\hline Kotei & South-East Quadrant & New Vitting & South-East Quadrant \\
\hline Source: Authadrath
\end{tabular}

Source: Author's Construct, 2010

Table 2: Households and Housing Characteristics in Kumasi and Tamale, 2010

\begin{tabular}{|l|l|l|}
\hline Indicator & Kumasi & Tamale \\
\hline Housing Units & 120 & 120 \\
\hline Households & 423 & 252 \\
\hline Population & 2436 & 1865 \\
\hline Rooms in Housing Units & 877 & 816 \\
\hline Mean Households Per House & 3.5 & 2.1 \\
\hline Mean Household Size & 5.8 & 7.4 \\
\hline Average Rooms per House & 7.3 & 6.8 \\
\hline Average Rooms Per Household & 2.1 & 3.2 \\
\hline Average Population per House & 20.3 & 15.5 \\
\hline
\end{tabular}

Source: Author's Construct, 2010

Table 3: Households Access to Bathing and Toilet Facilities in Kumasi and Tamale, 2010

\begin{tabular}{|l|l|l|l|l|}
\hline Housing Facility & Kumasi & \multicolumn{2}{l|}{ Tamale } \\
\hline Bathing & Frequency & Percentage & Frequency & Percentage \\
\hline Shared Bathhouse in House & & & & \\
\hline Open Cubicle Attached to House & 245 & 57.9 & 75 & 29.8 \\
\hline Open Space Around House & 46 & 10.9 & 66 & 26.2 \\
\hline Exclusive Bathhouse for Household & 28 & 6.6 & 19 & 7.5 \\
\hline Bath House in Another House & 94 & 22.2 & 87 & 34.5 \\
\hline Total & 10 & 2.4 & 5 & 2.0 \\
\hline Toilet & 423 & 100 & 252 & 100 \\
\hline Public Toilet (KVIP) & & & & \\
\hline Public Toilet (WC) & 82 & 19.4 & 54 & 21.4 \\
\hline Pit Latrine (in house) & 68 & 16.1 & 26 & 10.3 \\
\hline WC (in house) & 73 & 17.2 & 7 & 2.8 \\
\hline Free Range (Indiscriminate) & 150 & 35.5 & 29 & 11.5 \\
\hline KVIP (in house) & 15 & 3.5 & 108 & 42.9 \\
\hline Pan or Bucket (in house) & 28 & 6.6 & 19 & 7.5 \\
\hline Total & 7 & 1.7 & 9 & 3.6 \\
\hline Sourc: Aust & 423 & 100 & 252 & 100 \\
\hline
\end{tabular}

Source: Author's Construct, 2010 
Table 4: Construction Materials in Kumasi and Tamale, 2010

\begin{tabular}{|c|c|c|c|c|}
\hline \multirow[t]{2}{*}{ Construction Material } & \multicolumn{2}{|l|}{ Kumasi } & \multicolumn{2}{|l|}{ Tamale } \\
\hline & Frequency & Percentage & Frequency & Percentage \\
\hline \multicolumn{5}{|l|}{ Outer Wall } \\
\hline Cement Blocks & 105 & 87.5 & 53 & 44.2 \\
\hline Mud/Earth/Mud Brick & 11 & 9.2 & 51 & 42.5 \\
\hline Landcrete & 4 & 3.3 & 16 & 13.3 \\
\hline Total & 120 & 100 & 120 & 100 \\
\hline \multicolumn{5}{|l|}{ Roofing } \\
\hline Corrugated Metal Sheet & 97 & 80.8 & 89 & 74.2 \\
\hline Grass/Thatch/Bamboo & 3 & 2.5 & 23 & 19.2 \\
\hline Concrete & 9 & 7.5 & 3 & 2.5 \\
\hline Asbestos/Slate & 5 & 4.2 & 4 & 3.3 \\
\hline Other (Earth/Wood) & 6 & 5 & 1 & 0.8 \\
\hline Total & 120 & 100 & 120 & 100 \\
\hline \multicolumn{5}{|l|}{ Floor } \\
\hline Concrete & 102 & 85 & & 78.1 \\
\hline Mud/Earth & 5 & 4.2 & & 17.5 \\
\hline Terrazzo/Tiles & 10 & 8.3 & & 3.1 \\
\hline Wood & 3 & 2.5 & & 1.3 \\
\hline Total & 120 & 100 & 120 & 100 \\
\hline
\end{tabular}

Source: Author's Construct, 2010

Table 5: Households Occupancy Status

\begin{tabular}{|l|l|l|l|l|}
\hline \multirow{2}{*}{ Occupancy Status } & \multicolumn{2}{|l|}{ Number of Households } & \multicolumn{2}{l|}{ Tamale } \\
\cline { 2 - 5 } & Kumasi & Percentage & Frequency & Percentage \\
\hline & Frequency & 49.2 & 179 & 71.0 \\
\hline Owner & 208 & 33.1 & 62 & 24.6 \\
\hline Renting & 140 & 17.7 & 11 & 4.4 \\
\hline Rent Free & 75 & 100 & 252 & 100 \\
\hline Total & 423 & &
\end{tabular}

Source: Author's Construct, 2010

Table 6: Occupation of Rental Units by Households in Kumasi and Tamale, 2010

\begin{tabular}{|c|c|c|c|c|}
\hline \multirow[t]{3}{*}{ Occupancy Status } & \multicolumn{4}{|c|}{ Number of Households } \\
\hline & \multicolumn{2}{|c|}{ Kumasi } & \multicolumn{2}{|l|}{ Tamale } \\
\hline & Frequency & Percentage & Frequency & Percentage \\
\hline Apartment/Flat & 11 & 7.9 & 3 & 4.8 \\
\hline One Room & 83 & 59.3 & 21 & 33.9 \\
\hline Two Rooms & 24 & 17.1 & 18 & 29 \\
\hline Three or More Rooms & 22 & 15.7 & 20 & 32.3 \\
\hline Total & 140 & 100 & 62 & 100 \\
\hline
\end{tabular}

Source: Author's Construct, 2010

Table 7: Housing Affordability Indicators

\begin{tabular}{|l|l|l|}
\hline & Kumasi & Tamale \\
\hline Low Cost House $^{\mathbf{0}}$ & $\mathrm{GH} \phi 45,000$ & $\mathrm{GH} \phi 45,000$ \\
\hline Maximum Loan $\left(70 \%\right.$ of cost) $*^{*}$ & $\mathrm{GH} \phi 31,500$ & $\mathrm{GH} \phi 31,500$ \\
\hline Interest-rate $^{\mathrm{a}}$ & $28 \%$ & $28 \%$ \\
\hline Term (years) & 20 & 20 \\
\hline Annual Mortgage Payments & $\mathrm{GH} \phi 8,884$ & $\mathrm{GH} \phi 8,884$ \\
\hline Average Annual Household Income & & \\
\hline Maximum Payment-to-Income Ratio* & $\mathrm{GH} \phi 1,149$ & $\mathrm{GH} \phi 1,452$ \\
\hline Payment-to-Income Ratio of Households & & \\
\hline Downpayment (mortgage loan) - 30\% of cost* & $25 \%$ & $25 \%$ \\
\hline Annual Rental (three bedroom apartment) & $773 \%$ & $612 \%$ \\
\hline Rent-to-Income Ratio & $\mathrm{GH} \phi 13,500$ & $\mathrm{GH} \phi 13,500$ \\
\hline Minimum Rent Advance (three bedroom apartment) & $\mathrm{GH} \phi 2,400$ & $\mathrm{GH} \phi 1,920$ \\
\hline Minimum Rent Advance-to-Income Ratio & $209 \%$ & $132 \%$ \\
\hline Source: & $\mathrm{GH} \phi 2,400$ & $\mathrm{GH} \phi 1,920$ \\
\hline
\end{tabular}

Source: ${ }^{\circ}$ GREC (2009) * H.F.C. (2008), ${ }^{\mathrm{a}}$ BoG (2008), • GSS (2008)

Exchange rate: $\mathrm{US} \$ 1=\mathrm{GH} \propto 1.40$ 